\title{
ANALISIS PERATURAN MENTERI PENDIDIKAN NASIONAL INDONESIA NOMOR 70 TAHUN 2009 TENTANG PENDIDIKAN INKLUSIF YANG RAMAH ANAK
}

\author{
Lailatul Munawwaroh
}

Magister PGMI 2017 UIN Sunan Kalijaga Yogyakarta

Email: laelapgmi@gmail.com

\begin{abstract}
ABSTRAK
Penelitian ini bertujuan untuk menganalisis tentang pendidikan inklusif yang ramah anak dalam Peraturan Menteri Pendidikan Nasional Nomor 70 tahun 2009. Bentuk penelitian ini adalah deskriptif kualitatif. Metode yang digunakan adalah analisis isi yang bertujuan untuk menelaah isi dari suatu dokumen. Sumber data yang digunakan penelitian ini adalah dokumen. Sumber data dokumen yaitu berupa Peraturan Menteri Pendidikan Nasional Indonesia Nomor 70 tahun 2009 tentang Pendidikan Inklusif yang Ramah Anak. Analisis isi yaitu dengan mencatat dokumen atau arsip yang berkaitan erat dengan tujuan penelitian yakni pendidikan inklusif ramah anak. Prosedur analisis data dengan reduksi data, penyajian data, dan penarikan kesimpulan. Hasil penelitian menunjukkan bahwa pendidikan inklusif ramah anak adalah pendidikan yang tidak membedakan kelainan atau kebutuhan khusus peserta didik dalam hal fisik, mental, emosional, dan sosial dengan berpijak pada prinsip persamaan, keadilan, dan hak individu. Ada beberapa persoalan yang berkaitan dengan subtansi isi, seperti adanya segregasi pendidikan khusus dan reguler, adanya ketidaksinkronan peraturan perundangan yang berkaitan, kurangnya guru pembimbing khusus (GPK) dan keadaan masyarakat yang kurang mendukung dalam hal pelaksanaan pendidikan inklusif ramah anak.
\end{abstract}

Kata Kunci: Pendidikan, Inklusif, Ramah Anak. 


\section{ABSTRACT}

This study aims to determine child friendly inclusive education at stated regulation Minister of Education No, 70 of 2009. This research is a descriptive qualitative. This research using content analyze the purpose is to analyze document. Source of data used in the form of documents child friendly inclusive education at stated regulation Minister of Education No, 70 of 2009. Content analyze is recording documents or archives of the reserach, that is child friendly inclusive education. Procedure for analyzing data is data reduction, data display and conclusion drawing or verification.

The results of this study find that there is education that does not distinguish the abnormalities or special need of students in physical, mental,emotional and social based on principle of equality, justice adn individual rights. There are some issues is related to the substance of the content, such as the existence of segregation of special education and reguler, the synchronization of relevant laws and regulations, the lack of special guidance teachers (GPK) and the conditions of the community that are less supportive in terms of child friendly inclusive education.

\section{Keywords: $\quad$ Education, Inclusive, Child friendly.}

\section{A. PENDAHULUAN}

Pendidikan merupakan salah satu kebutuhan dasar bagi setiap orang, untuk mengembangkan kemampuan dan membentuk watak serta peradaban bangsa yang bermartabat, agar dapat mencerdaskan kehidupan bangsa, mengembangkan potensi, sehingga menjadi manusia beriman, bertakwa, berakhlak mulia, sehat, berilmu, cakap, kreatif, mandiri, dan menjadi warga negara yang demokratis serta bertanggung jawab. ${ }^{1}$ Akses pendidikan untuk setiap orang menjadi kata kunci bahwa setiap orang memiliki kesempatan yang sama. Pendidikan bermutu (baik) sangat berhubungan dengan manajemen (metode) pendidikan yang sesuai dengan kebutuhan, baik kesesuaiannya dengan potensi peserta didik ataupun potensi. Bahkan dalam deklarasi Universal Hak-Hak Asasi manusia (DUHAM), menyebutkan bahwa setiap orang

1. Undang-Undang Republik Indonesia Nomor 20 Tahun 2003 tentang Sistem Pendidikan Nasional, Pasal 3. 
berhak untuk hidup, mendapatkan kesempatan yang sama dan memperoleh perlakuan bermartabat tanpa diskriminasi. ${ }^{2}$

Begitu halnya dengan pendidikan bagi mereka yang mengalami kecacatan, juga harus tersedia dan disesuaikan dengan jenis kecacatannya atau secara inklusif. Kasus diskriminasi dunia pendidikan yang sering menjadi kritik untuk pemerintah adalah pendidikan untuk penyandang cacat atau yang sekarang dikenal dengan penyandang disabilitas. Disabilitas adalah keadaan fisik, mental, dan emosi yang terbatas, sebagaimana orang buta atau tuli. Oleh karena hal tersebut, ia tidak memiliki kemampuan untuk melihat atau mendengar. Difabel (different-able) atau perbedaan kemampuan ini, sudah tidak etis lagi dikatakan cacat. Karena pada dasarnya setiap orang memiliki kemampuan yang berbeda meskipun memiliki ukuran tubuh dan fisik yang sama. ${ }^{3}$

Sampai saat ini belum ada angka pasti tentang jumlah anak berkebutuhan khusus (ABK) di Indonesia. Namun, yang pasti jumlah mereka yang belum memperoleh hak pendidikan masih sangat banyak. Data resmi Direktorat PSLB tahun 2007 menyebutkan bahwa jumlah ABK yang sudah mengikuti pendidikan formal baru mencapai $24,7 \%$ atau 78.689 anak dari populasi anak cacat di Indonesia, yaitu 318.600 anak (Directorat PSLB, 2008). Ini artinya masih terdapat sebanyak 65,3\% ABK yang masih termarjinalisasikan dan terabaikan hak pendidikan. Bahkan angka tersebut diperkirakan dapat jauh lebih besar mengingat kecilnya angka prevalensi yang digunakan, yaitu $0,7 \%$ dari populasi penduduk serta masih buruknya sistem pendataan.

Pendidikan untuk penyandang disabilitas dijelaskan dalam undang-undang SISDIKNAS agar diselenggarakan melalui satuan pendidikan khusus atau secara inklusif. Kedua jenis pendidikan ini, diperuntukkan bagi penyandang disabilitas. Akan tetapi, pendidikan inklusif memungkinkan mereka belajar bersama siswa lain. ${ }^{4}$ Merespon hal ini, Kementrian Pendidikan Nasional menetapkan kebijakan No. 70 Tahun 2009, mengenai pendidikan inklusif bagi penyandang disabilitas. Pelaksanaan kebijakan ini perlu dikawal agar benar-benar melindungi (to protect), menghormati

2. Prastiyono, "Implementasi Kebijakan Pendidikan Inklusif (Studi di sekolah Galuh Handayani Surabaya)", DIA Jurnal Administrasi Publik, Vol. 11 No. 1 (Juni 2013).

3. Dedy Mulyasana, Pendidikan Bermutu dan Berdaya Saing (Bandung: Remaja Rosdakarya, 2012), hlm. 120-121.

4. M. Syafi'ie, "Sistem Hukum di Indonesia Diskriminatif kepada Difabel", Jurnal Difabel, Analekta Difabilitas, Vol. 2 No 2 (2015), hlm. 165. 
(to respect), dan memenuhi (to fulfill) hak pendidikan bagi penyandang disabilitas. Berdasarkan latar belakang diatas, maka dalam jurnal ini dideskripsikan tentang, bagaimana kebijakan Permendiknas Nomor 70 tahun 2009 dalam pendidikan inklusif ramah anak.

Hal ini juga disampaikan oleh Fatih Hendri Danarhadi pada penelitiannya yang diperoleh hasil bahwa seluruh komponen pendidikan di SMP Ekakapti Karangmojo sudah memenuhi syarat dalam penyelenggaraan pendidikan inklusi yang tertuang dalam Permendiknas No 70 tahun 2009 dalam prinsip-prinsip dasar pelaksanaan pendidikan inklusi. Sekolah ini juga bekomitmen untuk tetap memberikan pelayanan pendidikan bagi anak berkebutuhan khusus dan senantiasa meningkatkan kerja sama dengan pemerintah maupun masyarakat dalam membina anak berkebutuhan khusus. ${ }^{5}$

Diharapkan dengan adanya jurnal ini pembaca dapat, mengetahui kebijakan Permendiknas Nomor 70 tahun 2009 dalam pendidikan inklusif ramah anak dan hasil penelitian ini diharapkan mampu menambah khasanah keilmuan dan pengetahuan dalam dunia pendidikan pada umumnya dan khususnya mengenai beberapa ketentuan tertulis dari kebijakan Permendiknas Nomor 70 tahun 2009 tentang pendidikan inklusif ramah anak. Hasilnya dapat memberikan kontribusi penting bagi pemerhati dunia pendidikan khususnya yang berkaitan dengan pelaksanaan pendidikan inklusif di tingkat Sekolah Dasar/ Madrasah Ibtidaiyah serta dapat memberikan sumbangan pemikiran yang dapat dijadikan rujukan dalam mencari solusi dari problem ketidaksesuaian pelaksanaan pendidikan inklusif ramah anak.

\section{B. METODE PENELITIAN}

Penelitian ini merupakan penelitian literature melalui analisis dokumen berupa studi pustaka. Bentuk penelitian ini adalah deskriptif kualitatif yang berupa penggambaran dari suatu keadaan tertentu dengan menggunakan metode interaktif. Metode interaktif digunakan untuk menelaah isi dari suatu dokumen. Sumber data yang digunakan penelitian ini adalah dokumen. Sumber data dokumen yaitu berupa Peraturan Menteri Pendidikan Nasional Indonesia Nomor 70 tahun 2009 tentang Pendidikan Inklusif yang Ramah Anak.

Teknik pengumpulan data dalam penelitian ini adalah analisis isi. Analisis isi yaitu dengan mencatat dokumen atau arsip yang berkaitan erat dengan tujuan

5. Fatih Hendri Danarhadi, "Implementasi Kebijakan Pendidikan Inklusi di SMP Ekapati Karangmojo Gunung Kidul Yogyakarta", Jurnal Kebijakan Pendidikan Edisi 5 Vol VI Tahun 2017, hlm 542-543. 
penelitian. Analisis isi dilakukan dengan membahas konsep pendidikan inklusif yang ramah anak. Prosedur analisis data dengan reduksi data, penyajian data, dan penarikan kesimpulan. Reduksi data dilakukan dengan pengumpulan informasi dan data mengenai konsep pendidikan inklusif yang ramah anak dari pengumpulan dokumen. Kemudian penyajian data dilakukan dengan pemaparan informasi dengan menyederhanakan makna dan menginterpretasikan informasi. Selanjutnya, penarikan kesimpulan dilakukan dengan cara memberikan kesimpulan dari hasil penelitian sesauai dengan tujuan yang diharapkan oleh peneliti.

\section{HASIL PENELITIAN DAN PEMBAHASAN}

Pola pendidikan inklusif mempunyai pengertian yang beragam. Yang dimaksud beragam dalam hal ini adalah menampung semua siswa di kelas yang sama. Sekolah ini menyediakan program pendidikan yang layak, menantang, tetapi sesuai dengan kemampuan dan kebutuhan siswa. Lebih dari itu, sekolah inklusif juga merupakan tempat setiap anak dapat diterima, menjadi bagian dari kelas tersebut, dan saling membantu dengan guru dan teman sebayanya, maupun anggota masyarakat lain agar kebutuhan individualnya dapat terpenuhi. ${ }^{6}$

Pola pendidikan inklusif mempunyai pengertian yang beragam. Stainback mengemukakan bahwa sekolah inklusifadalah sekolah yang menampung siswa dikelas yang sama. Sekolah ini menyediakan program pendidikan yang layak, menantang, tetapi sesuai dengan kebutuhan setiap siswa. ${ }^{7}$ Lebih dari itu, sekolah inklusif juga merupakan tempat setiap anak dapat diterima, menjadi bagian dari kelas tersebut, saling membantu dengan guru dan teman sebayanya, maupun anggota masyarakat lain agar kebutuhan individualnya dapat terpenuhi. Staub dan Peck mengemukakan bahwa pendidikan inklusif adalah penempatan anak yang menunjukkan bahwa kelas reguler merupakan tempat belajar yang relevan bagi anak berkelainan, apapun jenis kelainannya dan bagaimanapun gradasinya.

Menurut Permendiknas Nomor 70 tahun 2009, pendidikan inklusif adalah sistem penyelenggaraan pendidikan yang memberikan kesempatan kepada semua peserta didik yang memiliki kelainan dan memiliki potensi kecerdasan dan atau bakat istimewa untuk mengikuti pendidikan atau pembelajaran dalam satu lingkungan pendidikan secara bersama-sama dengan peserta didik pada umumnya. Pendidikan inklusif

6. Akhmad Sholeh, Aksebilitas Penyandang Disabilitas Terhadap Perguruan Tinggi, (Yogyakarta: LkiS Pelangi Aksara, 2016), hlm.41.

7. Ibid., hlm.41. 
bertujuan: (1) memberikan kesempatan yang seluas-luasnya kepada semua peserta didik yang memiliki kelainan fisik, emosional, mental, dan sosial atau memiliki potensi kecerdasan dan atau bakat istimewa untuk memperoleh pendidikan yang bermutu sesuai dengan kebutuhan dan kemampuannya;(2) mewujudkan penyelenggaraan pendidikan yang menghargai keanekaragaman, dan tidak diskriminatif bagi semua peserta didik. $^{8}$

Sementara itu, Sapon-Shevin menyatakan bahwa pendidikan inklusif sebagai sistem layanan pendidikan yang mensyaratkan agar semua anak berkelainan dilayani di sekolah-sekolah terdekat di kelas reguler sama seperti teman seusianya. Oleh karena itu, ditekankan adanya restrukturisasi sekolah sehingga menjadi komunitas yang mendukung kebutuhan khusus setiap anak, artinya kaya dalam hal sumber belajar dan mendapat dukungan dari semua pihak, yaitu para siswa, guru, orang tua, dan masyarakat sekitarnya. Melalui pendidikan inklusif, anak berkelainan di didik bersama-sama dengan anak yang lainnya (normal) untuk mengoptimalkan potensi yang dimiliki. Hal ini dilandasi kenyataan bahwa di dalam masyarakat terdapat anak normal dan berkelainan yang tidak dapat dipisahkan dari suatu komunitas. Dengan demikian pendidikan inklusif berkenaan dengan aktivitas memberikan respons yang sesuai pada adanya perbedaan dari kebutuhan belajar yang baik. Ia merupakan pendekatan yang memperhatikan bagaimana mentransformaskan sistem pendidikan sehingga mampu merespons keagamaan siswa dan memungkinkan guru dan siswa merasa nyaman dengan keragaman dan melihatnya lebih sebagai suatu tantangan dan pengayaan dalam lingkungan belajar daripada sebagai problem. ${ }^{9}$

\section{Pendidikan Inklusif Ramah Anak}

Pendidikan inklusif ramah anak sebagai sebuah pendekatan untuk memenuhi kebutuhan pendidikan dan belajar bagi semua anak, remaja dan orang dewasa. Pendidikan inklusif ramah anak difokuskan secara spesifik kepada mereka yang rawan dan rapuh, terpinggirkan dan terabaikan. Pendidikan inklusif ramah anak mempunyai arti bahwa pendidikan atau sekolah harus mengakomodasi semua anak tanpa mempedulikan keadaan fisik, intelektual, sosial, emosi, bahasa, atau konsidi-kondisi lain, termasuk anak-anak berbakat (gifted children), pekerja anak dan anak jalanan, anak di daerah terpencil, anak-anak dan kelompok etnik

8. Peraturan Menteri Pendidikan Nasional Nomor 70 Tahun 2009 tentang Pendidikan Inklusif.

9. Akhmad Sholeh, Aksebilitas Penyandang Disabilitas Terhadap Perguruan Tinggi, (Yogyakarta: LkiS Pelangi Aksara, 2016), hlm.42. 
dan bahasa minoritas dan anak-anak yang tidak beruntung dan terpinggirkan dari kelompok masyarakat.(Salamanca Statement, 1994) Peraturan Menteri Pendidikan Nasional Nomor 70 tahun 2009

Menurut Permendiknas Nomor 70 tahun 2009, pendidikan inklusif adalah sistem penyelenggaraan pendidikan yang memberikan kesempatan kepada semua peserta didik yang memiliki kelainan dan memiliki potensi kecerdasan dan/ atau bakat istimewa untuk mengikuti pendidikan atau pembelajaran dalam satu lingkungan pendidikan secara bersama-sama dengan peserta didik pada umumnya. Pendidikan inklusif bertujuan: (1) memberikan kesempatan yang seluas-luasnya kepada semua peserta didik yang memiliki kelainan fisik, emosional, mental, dan sosial atau memiliki potensi kecerdasan dan atau bakat istimewa untuk memperoleh pendidikan yang bermutu sesuai dengan kebutuhan dan kemampuannya; (2) mewujudkan penyelenggaraan pendidikan yang menghargai keanekaragaman, dan tidak diskriminatif bagi semua peserta didik. ${ }^{10}$

Kebijakan mengenai penyandang disabilitas, sebagaimana tercantum dalam UUD 1945 Pasal 31 ayat 1 menyatakan bahwa: "setiap warga negara berhak mendapat pendidikan. Sedangkan UU Sisdiknas Nomor 20 Tahun 2003 pasal 5 menyebutkan bahwa: "setiap warga negara mempunyai hak yang sama untuk memperoleh pendidikan yang bermutu". Kemudian dalam UU Nomor 4 tahun 1997 tentang penyandang cacat mempunyai kesamaan dan kesempatan untuk mendapatkan pendidikan pada satuan, jalur, jenis dan jenjang pendidikan sesuai dengan jenis derajat kecacatannya. Sementara pasal 12 menyatakan bahwa: "setiap lembaga pendidikan memberikan kesempatan yang sama kepada penyandang cacat sebagai peserta didik pada satuan, jalur, jenis dan jenjang pendidikan sesuai dengan jenis dan derajat kecacatan serta kemampuannya."

Begitu juga yang tertuang dalam Peraturan Menteri Pendidikan Nasional Nomor 70 Tahun 2009, pasal 3 yang berbunyi: (1) Setiap peserta didik yang memiliki kelainan fisik, emosional, mental, dan sosial atau memiliki potensi kecerdasan dan atau bakat istimewa berhak mengikuti pendidikan secara inklusif pada satuan pendidikan tertentu sesuai dengan kebutuhan dan kemampuannya; (2) Peserta didik yang memiliki kelainan sebagaimana dimaksud dalam ayat (10) terdiri atas: a) tunanetra; b) tunarungu; c) tunawicara; d) tunagrahita; e) tunadaksa; f) tunalaras;

10. Peraturan Menteri Pendidikan Nasional Nomor 70 tahun 2009 tentang Pendidikan Inklusif. 
g) berkesulitan belajar; h) lamban belajar; i) autis; j) memiliki gangguan motorik; k) menjadi korban penyalahgunaan narkoba, obat terlarang, dan zat adiktif lainnya; 1) memiliki kelainan lainnya; m) tunaganda. Sedangkan dalam pasal 8 berbunyi: "pembelajaran pada pendidikan inklusif mempertimbangkan prinsip-prinsip pembelajaran yang disesuikan dengan karakteristik belajar peserta didik". Pasal 9; (1) penilaian hasil belajar bagi peserta didik pendidikan inklusif mengacu pada jenis kurikulum tingkat satuan pendidikan yang bersangkutan; (2) peserta didik yang mengikuti pembelajaran berdasarkan kurikulum yang dikembangkan sesuai dengan standar nasional pendidikan atau di atas standar nasional pendidikan wajib mengikuti ujian nasional; (3) peserta didik yang memiliki kelainan dan mengikuti pembelajaran berdasarkan kurikulum yang dikembangkan di bawah standar pendidikan mengikuti ujian yang diselenggarakan oleh satuan pendidikan yang bersangkutan; (4) peserta didik yang menyelesaikan dan lulus ujian sesuai dengan standar nasional pendidikan mendapatkan ijazah yang blankonya dikeluarkan oleh Pemerintah; (5) peserta didik yang memiliki kelainan yang menyelesaikan pendidikan berasarkan kurikulum yang dikembangkan oleh satuan pendidikan di bawah standar nasional pendidikan mendapatkan surat tanda tamat belajar yang blankonya dikeluarkan oleh satuan pendidikan yang bersangkutan; (6) Peserta didik yang memperoleh surat tanda tamat belajar dapat melanjutkan pendidikan pada tingkat atau jenjang yang lebih tinggi pada satuan pendidikan yang menyelenggarakan pendidikan inklusif atau satuan pendidikan khusus. ${ }^{11}$

\section{Aksebilitas Penyandang Disabilitas}

Aksebilitas di sini diklasifikasikan ke dalam dua macam, yaitu asksebilitas fisik dan aksebilitas non-fisik:

\section{Aksebilitas Fisik}

Aksebilitas fisik meliputi bangunan gedung sekolah, ruang kuliah, tempat parkir, toilet/ kamar mandi, jalur pedestrian, dan sarana-sarana lainnya seperti ruang ibadah (musholla/ masjid), auditorium, perpustakaan, laboratorium, ruang administrasi, ruang pimpinan, dan fasilitas pendidikan yang lain sebagai media pembelajaran.

\section{Aksebilitas Non-Fisik}

Pada hakikatnya, prinsip-prinsip desain universal tidak hanya diterapkan pada aksebilitas fisik saja, tetapi bisa juga diterapkan pada aksebilitas non-fisik dalam

11. Peraturan Menteri Pendidikan Nasional Nomor 70 tahun 2009 tentang Pendidikan Inklusif. 
dunia pendidikan. Diantaranya yakni: a) pelayanan institusi yang sensitif dan sesuai dengan kebutuhan penyandang disabilitas di setiap unit; b) modifikasi desain pembelajaran, kurikulum yang akomodatif, evaluasi, sarana dan prasarana dalam proses pembelajaran terhadap penyandang disabilitas. ${ }^{12}$

\section{Analisis Permendiknas Nomor 70 tahun 2009 tentang Pendidikan Inklusif}

Pendidikan inklusif ramah anak yang mendasarkan konsep-konsep tentang; anak, sistem pendidikan, keragaman dan diskriminasi, proses memajukan inklusi, dan konsep tentang sumber daya. Secara terperinci dapat dilakukan analisis sebagai berikut:

\section{Analisis dari segi hukum atau yuridis}

\section{Kesepakatan Internasional}

Secara internasional terdapat beberapa kesepakatan yang ditandatangani oleh perwakilan setiap negara dan organisasi non-pemerintah tentang pendidikan inklusif ramah anak yaitu: a) Konvensi PBB 1948 tentang HAM: b) Konvensi PBB tentang Hak Anak; c) Aturan Standar PBB 1990, tentang kesamaan hak bagi penyandang cacat; d) kesepakatan tentang pendidikan untuk semua 1990; e) Pernyataan Salamanca 1994, tentang pendidikan kebutuhan khusus dan pendidikan inklusif ramah anak; f) kerangka aksi Dakar 1990, tentang pendidikan untuk semua; g) Deklarasi Bandung 2004, tentang pendidikan iklusif ramah anak; h) Deklarasi Bangkok 2004, menyatakan bahwa mutu pendidikan ditandai oleh 3 komponen yaitu: inklusif, responsive gender, lingkungan belajar yang sehat dan melindungi; i) Rekomendasi Simposium Internasional Bukit tinggi 2005, menyatakan bahwa pendidikan inklusif ramah anak harus dipandang sebagai pendekatan yang menjamin bahwa penerapan pendidikan untuk semua benarbenar untuk semua; j) Konvensi PBB 2006 tentang Hak Asasi bagi penyandang cacat yang telah diratifikasi melalui UU No. 19 tahun $2011 .^{13}$

\section{Komitmen Pemerintah Indonesia Menuju Pendidikan Inklusif Ramah Anak}

Upaya yang dilakukan oleh pemerintah Republik Indonesia dalam mengimplementasikan pendidikan inklusif ramah anak diawali pada tahun 1990, melalui program kerja sama antara Kementrian Pendidikan Nasional pemerintah

12. Akhmad Sholeh, Aksebilitas Penyandang Disabilitas Terhadap Perguruan Tinggi, (Yogyakarta: LkiS Pelangi Aksara, 2016), hlm.53.

13. Dedy Kustawan, Model Implementasi Pendidikan Inklusif Ramah Anak, (Jakarta: PT. Luxima Metro Media, 2013), hlm. 16-18. 
Republik Indonesia dengan Pemerintah Kerajaan Norwegia. Program kegiatan difokuskan pada hal-hal sebagai berikut: 1) penyebarluasan idiologi pendidikan inklusif ramah anak melalui seminar dan lokakarya; 2) dilakukan uji coba perluasan peran dan fungsi SLB menjadi pusat dan untuk menyelengarakan sekolah inklusf; 3) melibatkan LSM dan organisasi internasional dalam membantu mengimplementaskan pendidikan inklusif ramah anak; 4) memulai kegiatan piloting sekolah inklusif di beberapa provinsi, dan 5) mendirikan program master pendidikan kebutuhan khusus dan pendidikan inklusif sebagai upaya menyediakan sumberdaya manusia yang kompeten dalam pendidikan inklusif ramah anak. ${ }^{14}$

Selain itu, sebagai bukti bahwa pemerintah memiliki komitmen yang tinggi dalam memajukan pendidikan inklusif ramah anak, telah diterbitkan Undangundang Nomor 20 Tahun 2003 tentang Sistem Pendidikan Nasional, Peraturan Menteri Pendidikan Nasional Nomor 70 Tahun 2009 tentang Pendidikan Inklusif bagi Peserta Didik yang Memiliki Kelainan dan Memilki Potensi Kecerdasan dan atau Bakat Istimewa dan Peraturan Pemerintah Nomor 17 tahun 2010 tentang Pengelolaan dan Penyelenggaraan pendidikan. ${ }^{15}$

\section{Segregrasi antara pendidikan khusus dengan reguler}

Hakikat pendidikan inklusif diantaranya adalah penggabungan pendidikan reguler dengan pendidikan khsusus kedalam satu sistem sekolah, yang dipersatukan untuk mempertemukan perbedaan kebutuhan siswa. Akan tetapi hakikat pendidikan inklusif ini tidak sesuai dengan UU No. 20 tahun 2003 tentang Sistem Pendidikan Nasional, pasal 5 ayat 2 yang mengemukakan bahwa: "warga negara yang memiliki kelainan fisisk, emosional, mental, intelektual, dan atau sosial, berhak memperoleh pendidikan khusus". Lebih lanjut disebut dalam pasal 15 bahwa "Jenis pendidikan mencakup pendidikan umum, kejuruan, akademik, profesi, vokasi, keagamaan, dan khusus". Pengertian pendidikan khusus merupakan pendidikan bagi peserta didik yang memiliki tingkat kesulitan dalam mengikuti proses pembelajaran karena kelainan fisik, emosional, mental, sosial, dan atau memiliki potensi kecerdasan dan bakat istimewa.

Isi dan ketentuan pasal 5, pasal 15 dan pasal 32 UU Sisdiknas tersebut diatas menunjukkan bahwa terdapat kelompok "khusus", yaitu warga negara yang memiliki kelainan dan kecerdasan luar biasa sehingga memerlukan pendidikan

14. Ibid., hlm. 18-19.

15. Ibid., hlm. 19. 
khusus. Hal ini, menunjukkan adanya orientasi pendidikan yang cenderung bersifat "segregatif" dan belum berorientasi "inklusif", karena di dalam UU No. 20 Tahun 2003 Tentang Sistem Pendidikan Nasional, belum mengemukakan secara khusus istilah "pendidikan inklusif". Dengan demikian, jelas bahwa adanya segregrasi bertentangan dengan hakikat pendidikan inklusif sebagaimana dikemukakan dalam pernyataan Salamanca dan kerangka pendidikan inklusif dalam pasal 7 bahwa “ prinsip mendasar dari sekolah inklusif adalah, bahwa semua anak seyogyanya belajar bersama-sama tanpa memandang kesulitan ataupun perbedaan yang ada pada diri mereka".

Permasalahan isi substansi dalam pasal-pasal UU tersebut diatas, membawa implikasi pada pelaksanaan di lapangan. Kajian yang dilakukan tentang Penuntasan Wajib Belajar Sembilan Tahun, ditemukan masih terdapat pandangan masyarakat, bahkan pengelola pendidikan termasuk guru bahwa: calon siswa yang mempunyai hambatan dan cacat memang lebih tepat bersekolah di Sekolah Luar Biasa (SLB). Di samping ini, pendidikan reguler juga cenderung menolak siswa penyandang cacat. Tanpa SLB, mereka mungkin tidak memperoleh kesempatan pendidikan atau tidak dapat mengakses kurikulum di sekolah reguler. Hal ini juga berkaitan dengan kurangnya sosialisasi tentang pendidikan inklusif, bahwa sekolah reguler atau umum harus bersedia menerima calon siswa yang mempunyai hambatan fisik dan nonfisik. ${ }^{16}$

\section{Ketidaksinkronan peraturan tentang penyediaan guru pembimbing khusus}

Berkaitan dengan tenaga pengajar untuk pendidikan inklusif yaitu adanya guru pembmibing khusus (GPK), yang menyatakan bahwa setiap satuan pendidikan untuk menyediakan guru khusus yang mempunyai kompetensi. Kondisi ini menunjukkan ketidaksinkronan peraturan tentang penyediaan guru pembimbing khusus, yang berimplikasi terhadap kualitas layanan pada pendidikan inklusif.

Hal ini juga tertuang dalam Peraturan Menteri Pendidikan Nasional nomor 70 tahun 2009 pasal 2 tentang pendidikan inklusif yang bertujuan untuk: (a) "memberikan kesempatan yang seluas-luasnya kepada peserta didik yang memiliki kelainan fisik, emosional, mental, dan sosial, atau memiliki potensi kecerdasan dan/ atau bakat istimewa untuk memperoleh pendidikan yang bermutu sesuai dengan bakat dan kemampuannya." (b) "mewujudkan penyelenggaraan pendidikan yang

16. Titik Handayani,d.k.k, Peraturan Perundangan dan Implemetasi Pendidikan Inklusif, Jurnal Masyarakat Indonesia, Vol. 39, No. 1 (Juni 2013). 
menghargai keanekaragaman, dan tidak diskriminatif bagi semua peserta didik sebagaimana yang dimaksud pada huruf a". ${ }^{17}$

Sesuai dengan UU SISDIKNAS No.20 tahun 2003 mengenai wajar 9 tahun yaitu setiap warga negara usia sekolah berhak memperoleh pemerataan pendidikan yang layak dan bermutu, sehingga pemerintah kini lebih bijak dengan memberi perhatian bagi masyarakat yang berkebutuhan khusus agar bisa belajar sejajar dengan mereka yang normal dengan menyelenggarakan pendidikan inklusif. Peraturan Menteri Pendidikan Nasional Republik Indonesia No.70 Tahun 2009 tentang Pendidikan Inklusif bagi peserta didik yang memiliki kelainan dan memiliki potensi kecerdasan dan/ atau bakat istimewa serta. Sekolah ini merupakan sekolah yang menerima anak berkebutuhan khusus untuk dapat belajar bersama dengan peserta didik yang normal.

Manajemen sekolah akan efektif dan efisien apabila didukung oleh sumber daya manusia yang professional untuk mengoperasikan sekolah, kurikulum yang sesuai dengan tingkat perkembangan dan karakteristik siswa, kemampuan dan task commitment (tanggung jawab terhadap tugas) tenaga kependidikan yang handal, sarana prasarana yang memadai untuk mendukung kegiatan belajar mengajar, dana yang cukup untuk menggaji staf sesuai dengan fungsinya, serta partisipasi masyarakat yang tinggi. Apabila salah satu hal di atas tidak sesuai dengan yang diharapkan dan/ atau tidak berfungsi sebagaimana mestinya, maka efektivitas dan efisiensi pengelolaan sekolah kurang optimal. Manajemen sekolah, memberikan kewenangan penuh kepada kepala sekolah untuk merencanakan, mengorganisasikan, mengarahkan, mengkoordinasikan, mengawasi, dan mengevaluasi komponen-komponen pendidikan suatu sekolah yang meliputi input siswa, tenaga kependidikan, sarana prasarana, dana, manajemen, lingkungan, dan kegiatan belajar mengajar.

\section{Keadaan Masyarakat yang Kurang Mendukung Pendidikan Inklusif Ramah} Anak

Bahwa pandangan pemangku kepentingan pendidikan inklusif dan masyarakat, guru maupun kepala sekolah. Hal ini disebabkan karena banyak orang tua yang kebanyakan enggan mengirim anak berkebutuhan khusus ke sekolah biasa, karena khawatir akan adanya penolakan atau diskriminasi. Bahkan kebanyakan masyarakat yang mempunyai anak berkebutuhan khusus merasa malu dan enggan, untuk menyekolahkan anak pada sekolah reguler.

17. Ibid., hlm. 39 .

184 AL-BIDAYAH, Volume 10, Nomor 02, Desember 2018 


\section{KESIMPULAN}

Pendidikan inklusif ramah anak adalah pendidikan yang tidak membedakan kelainan atau kebutuhan khusus peserta didik dalam hal fisik, mental, dan emosional, dan sosial dengan berpijak dengan prinsip persamaan, keadilan, dan hak individu.

Ada beberapa persoalan berkaitan dengan subtansi isi, seperti adanya segregasi pendidikan khusus dan reguler, adanya ketidaksinkronan peraturan perundangan yang berkaitan, kurangnya guru pembimbing khusus dan keadaan masyarakat yang kurang mendukung dalam hal pelaksanaan pendidikan inklusif ramah anak. Adapun saran dari peneiti untuk pendidikan inklusif yang ramah anak adalah sebagai berikut:

1. Adanya perangkat perundang-undangan dan kebijakan pemerintah, telah mendukung ke arah penyelengaraan pendidikan inklusif, meskipun peraturan perundangan yang ada masih perlu disempurnakan dan yang lebih penting perlu disosialisasikan.

2. Kendala minimnya sarana penunjang sistem pendidikan inklusif ramah anak, sebagai saran untuk pemerintah memperhatikan sarana dan prasarana bagi anak inklusi.

3. Pejabat berwenang perlu mencanangkan kurikulum yang mengakomodasi pendidikan inklusi ramah anak.

\section{E. DAFTAR PUSTAKA}

Danarhadi, Fatih Hendri, "Implementasi Kebijakan Pendidikan Inklusi di SMP Ekapati Karangmojo Gunung Kidul Yogyakarta", Jurnal Kebijakan Pendidikan Edisi 5 Vol VI Tahun 2017, hlm 542-543.

Handayani, Titik d.k.k. Peraturan Perundangan dan Implemetasi Pendidikan Inklusif. Dalam Jurnal Masyarakat Indonesia, Vol. 39, No. 1 Tahun. 2013.

Kustawan, Dedy. Model Implementasi Pendidikan Inklusif Ramah Anak. Jakarta: PT. Luxima Metro Media, 2013.

Mulyasana, Dedy. Pendidikan Bermutu dan Berdaya Saing. Bandung: Remaja Rosdakarya, 2012.

Peraturan Menteri Pendidikan Nasional Nomor 70 tahun 2009 tentang Pendidikan Inklusif.

Prastiyono. "Implementasi Kebijakan Pendidikan Inklusif (Studi di sekolah Galuh Handayani Surabaya)". Jurnal DIA Jurnal Administrasi Publik, Vol. 11 No. 1 Tahun, 2013. 
Sholeh, Akhmad. Aksebilitas Penyandang Disabilitas Terhadap Perguruan Tinggi. Yogyakarta: LkiS Pelangi Aksara, 2016.

Syafi'ie, M. "Sistem Hukum di Indonesia Diskriminatif kepada Difabel”. Dalam Jurnal Difabel, Analekta Difabilitas, Vol. 2 No 2 Tahun, 2015.

Undang-Undang Republik Indonesia Nomor 20 Tahun 2003 tentang Sistem Pendidikan Nasional. 